\title{
EFFECT OF BILIARY FISTULA ON BROMSULPHALEIN RETENTION, SERUM PHOSPHATASE, AND BILE PHOSPHATASE
}

\author{
By VICTOR A. DRILL, ${ }^{1}$ J. A. ANNEGERS, E. F. SNAPP, AND A. C. IVY \\ (From the Department of Physiology, Northwestern University Medical School, Chicago)
}

(Received for publication. June 8, 1944)

The production of biliary fistulas in dogs has been used for many years as an experimental procedure for studying factors influencing bile flow, the excretion of drugs in the bile, and the metabolism and excretion of bile pigments and bile acids. No particular attention has been paid to the possible effect that the biliary fistula may have on hepatic function. We have recently reported that 9 biliary fistula dogs all showed an abnormal retention of bromsulphalein (5 mgm. dose) and a rise in serum phosphatase, which persisted in the dogs for 60 to 80 days, the maximum period of observation (1). These observations are of interest because of the relation of hepatic function to the various aspects of bile metabolism, and also the use of T-tube drainage of the common bile duct in man. The preliminary report has been confirmed on a further series of bile fistula dogs, which are reported in the present paper.

A total of 14 cholecystectomized-biliary fistula dogs were studied to observe: (1) any effect of the operation on liver function, as measured by bromsulphalein retention and serum phosphatase values; and (2) the relation of the level of serum phosphatase to the excretion of phosphatase in the bile. Studies were also made on the liver function of 6 internal-biliary fistula dogs by means of the bromsulphalein and serum phosphatase tests.

\section{METHODS}

Twenty dogs weighing between 7.7 and $15.6 \mathrm{kgm}$. were used. Fourteen of the dogs were cholecystectomizedbiliary fistula dogs operated under ether anesthesia. The biliary fistula employed was similar to that of Rous and McMaster (2), except that the rubber catheter was inserted through the cystic.duct into the common bile duct, the common bile duct being ligated and severed near the duodenum. In some of the dogs, a small rubber tube was placed in the duodenum so that bile could be returned.

1 National Research Council Fellow 1942-1943. Present address, Department of Pharmacology, Yale University School of Medicine, New Haven, Connecticut.
In most dogs, however, instead of returning bile, 1.5 grams of bilron were administered orally twice a day, and a normal output of bile maintained. No difference in results was observed between dogs from which bile was returned and dogs to which bilron was fed. In some dogs, bile was collected under a small amount of suction $(3,4)$, but again the results did not differ from those obtained when the bile was collected without suction. The dogs were fed twice a day, the diet consisting of "Pard" and milk, supplemented with cod liver oil and yeast. Feeding the animals 2 , or especially 3 times a day produces a more constant output of bile and cholic acid than does a single daily feeding $(3,4)$.

Studies were also made on 6 internal biliary fistula dogs, in which the gallbladder was connected to the renal pelvis, the common bile duct being ligated.2

Alkaline phosphatase was determined in the serum and bile according to the method of Bodansky (5), beta glycerophosphate being used as substrate. It was found best to allow the bile sample plus trichloroacetic acid to stand over night before filtering and determining phosphates. Bromsulphalein retention was determined as previously used on dogs $(6,7)$. Five mgm. of dye per $\mathrm{kgm}$. of body weight was injected intravenously and a blood sample taken one-half hour later. The alkalinized serum was read against the $2 \mathrm{mgm}$. standards $(4 \mathrm{mgm}$. of dye per $100 \mathrm{ml}$. equivalent to 100 per cent) in a block comparator using a blue glass filter. It is more difficult to determine the amount of dye with a higher concentration of standards. Thus, with the $5 \mathrm{mgm}$. dose and the original set of standards, the bromsulphalein retention may range above 100 per cent during liver damage.

\section{EXPERIMENTAL PROCEDURE}

Control values for serum phosphatase and bromsulphalein retention were determined, the individual control values being shown in the graphs. In all of the dogs, the control serum phosphatase varied between 3.45 and 6.19 units per $100 \mathrm{ml}$. of serum, most of the values being less than 5.0 units. The bromsulphalein retention at the end of one-half hour was between 5 and 12 per cent. Values of 15 per cent or above were therefore regarded as abnormal.

2 The authors wish to thank Doctor Smith Freeman for permitting the liver function tests to be performed on 6 of his internal-biliary fistula dogs. 
The broken horizontal line on the graphs represents the upper limit of normal of bromsulphalein retention and the approximate upper limit of normal for serum phosphatase. After operation, bile phosphatase was determined each day. After the initial changes in bile phosphatase had become evident, bile phosphatase was determined every 2 or 3 days. The dogs were studied for 14 to 84 days post-operatively.

\section{LIVER FUNCTION}

All the cholecystectomized-biliary fistula dogs showed an abnormal liver function post-operatively. Either the serum phosphatase or bromsulphalein retention tests, or both, were above normal in from 1 to 12 days after operation (Figures 1 to 9). As expected, the degree of change in hepatic function varied in the 14 dogs.
Dog No. 55 (Figure 9) showed the least change in liver function during the period of observation. Two other dogs (Nos. 53 and 66; Figure 1) gave evidence of abnormal hepatic function shortly after operation, but had returned to normal for a period during the experiment. In the other 11 dogs, either one or both liver function tests remained abnormal during the experiment. No obstruction was present, and bile volume was normal during the development of the abnormal liver function.

The serum phosphatase test and bromsulphalein retention gave simultaneous evidence of damaged liver function in most of the 14 dogs. However, in 3 dogs, the serum phosphatase test gave better indications of hepatic damage than did the bromsulphalein test (Figure 1, Dogs 66 and 69; Figure 2, Dog 90). The reverse was
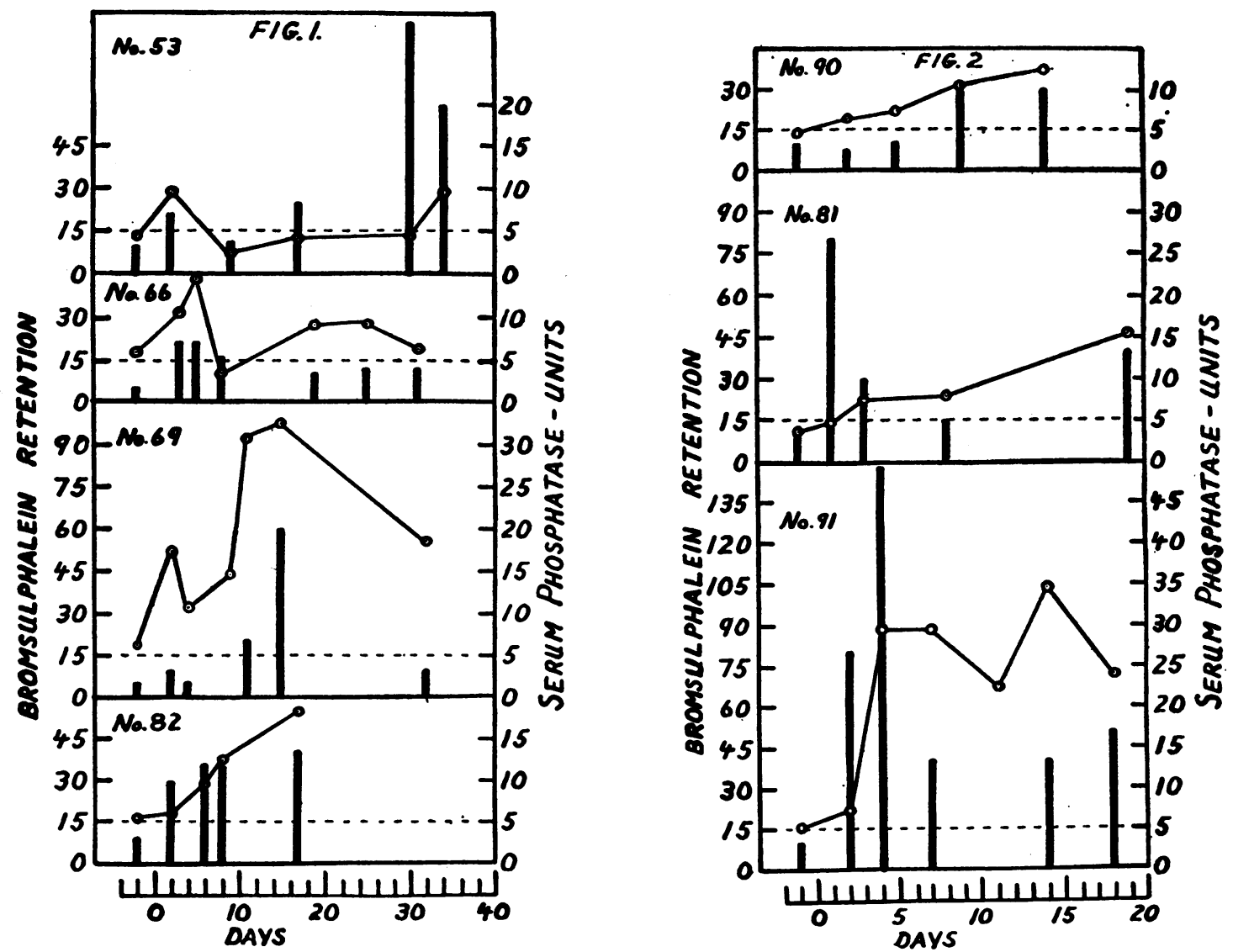

Figs. 1 and 2. Bromsulphalein Retention and Serum Phosphatase of Cholecystectomized-Biliary Fistula Dogs Following Operation.

The dotted horizontal line indicates the upper limit of normal bromsulphalein retention, and the approximate upper limit of normal for serum phosphatase. Solid bars, bromsulphalein; circles, phosphatase units. 
true in dog No. 53 (Figure 1), where the serum phosphatase was normal while the dye retention was abnormal. Both tests showed good agreement in the remaining 10 dogs. It seems evident that hepatic dysfunction will occur in cholecystectomized-bile fistula dogs after operation, and that one or both liver function tests remained abnormal in 13 of 14 dogs during the experiment.

\section{BILE PHOSPHATASE}

Bile phosphatase was determined in a 24-hour sample of bile and is expressed in the graphs as units per $100 \mathrm{ml}$. of bile. "Fresh" samples of bile contained about 6 more units of phosphatase per $100 \mathrm{ml}$. of bile than did the 24-hour sample. As the degree and direction of change were the same in the preliminary tests, the 24-hour sample of bile was used for phosphatase determination in all of the reported data. Bile volume and total bile phosphatase per 24 hours are also shown in the graphs.

Changes in bile phosphatase were found that could be correlated with serum phosphatase values. This interrelationship was rendered somewhat difficult because of the lack of knowledge of normal bile phosphatase values, and, as was found, the output of bile phosphatase may be abnormal immediately following operation. Serum phosphatase values above normal following operation may be due to either: (1) inability of the dogs to secrete bile phosphatase normally, which would lead to an increased blood level; or (2) overproduction of phosphatase, resulting in increased biliary excretion, but if not excreted rapidly enough would again result in abnormal serum phosphatase values. In either case, dogs with serum phosphatase values above normal following the operation would not be likely to have a normal output of bile phosphatase.

Three dogs had normal serum phosphatase values for a short time following operation. It may be assumed that the output of bile phosphatase during this period was normal, so that the following data on normal bile phosphatase were obtained:

1. Dog 45, 6 to 23 units of phosphatase per $100 \mathrm{ml}$. of bile, with a total of 10 to 40 units of bile phosphatase in 24 hours (Figure 3).
2. Dog 51,13 to 37 units of phosphatase per $100 \mathrm{ml}$. of bile, with a total of 9 to 49 units of bile phosphatase in 24 hours (Figure 7).

3. Dog 54,3 to 8 units of phosphatase per $100 \mathrm{ml}$. of bile, with a total of 5 to 11 units of bile phosphatase in 24 hours (Figure 4).

There is one possible objection to this reasoning,-if the liver were damaged the production of "liver" phosphatase might be below normal, so that phosphatase could be excreted rapidly enough to maintain a normal blood level. This would give us a normal bile phosphatase that was too low. However, the bromsulphalein retention during this period was normal in dogs 45 and 54 and only slightly above normal (20 per cent retention) in $\operatorname{dog} 51$, which renders this possibility unlikely. From the above 3 dogs, the normal bile phosphatase can be said to vary between 3 to 37 units per $100 \mathrm{ml}$. of bile with a total 24-hour output of 5 to 49 units.

\section{RELATION OF RISE IN BILE PHOSPHATASE TO} SERUM PHOSPHATASE, 3 DOGS

Dog No. 45 showed an increase in serum phosphatase that was correlated with an increased output of bile phosphatase. Coincident with the rise in serum phosphatase, the level of bromsulphalein retention also increased (Figure 3 ). Bile volume remained in the normal range, and there was therefore an increase in the 24-hour output of bile phosphatase. A similar result was observed in dog 54 (Figure 4). In this $\mathrm{dog}$, the initial level of bile phosphatase was low, but again the rise in bromsulphalein retention and in serum phosphatase was associated with an increase in bile phosphatase. The total bile phosphatase per 24 hours also increased. Bile volume remained normal until the fiftieth day, on which the dog suddenly became obstructed and was discarded. Dog No. 50 maintained a high bile phosphatase (30 to 60 units per $100 \mathrm{ml}$.) throughout the experiment, excreting a total of 25 to 100 units of bile phosphatase per 24 hours. Correlated with this high phosphatase excretion was a marked increase in serum phosphatase above the level of the previous 2 dogs, together with an increased retention of bromsulphalein (Figure 5). These 3 dogs show that a high serum phosphatase value can be 


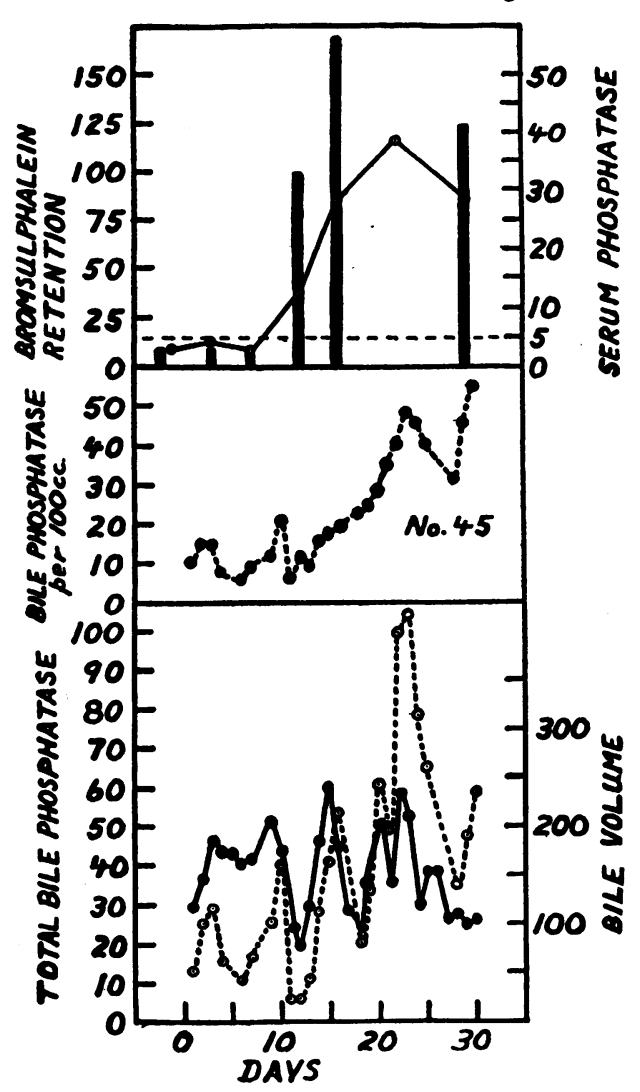

FIG. 3

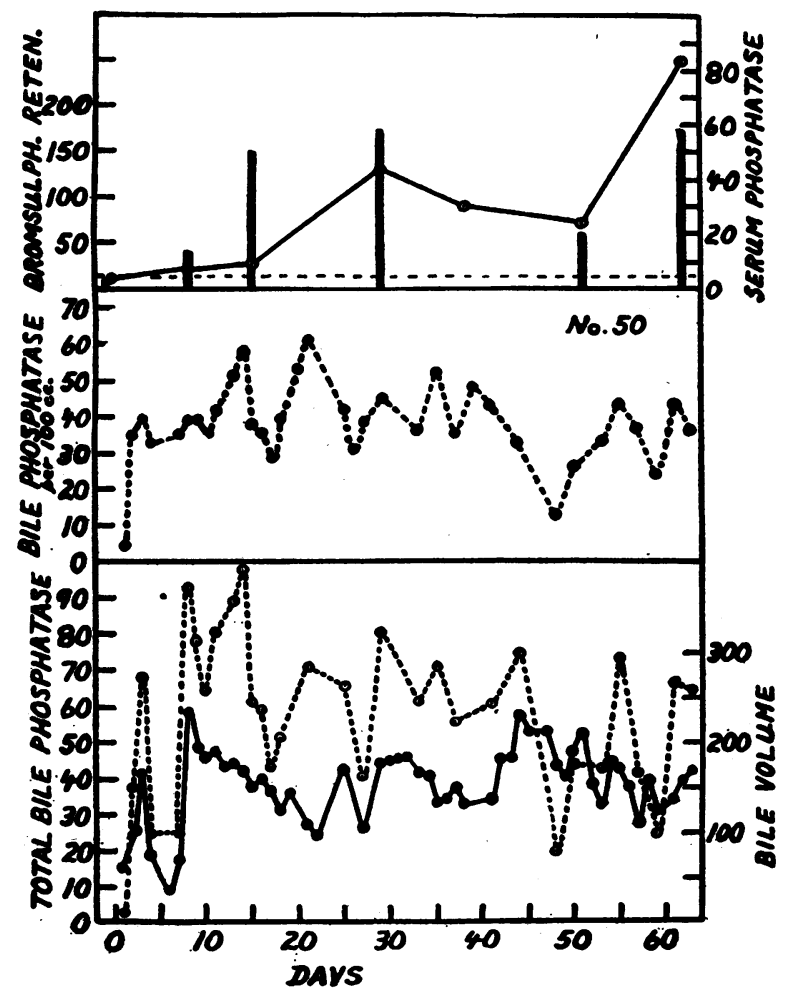

FIG. 5

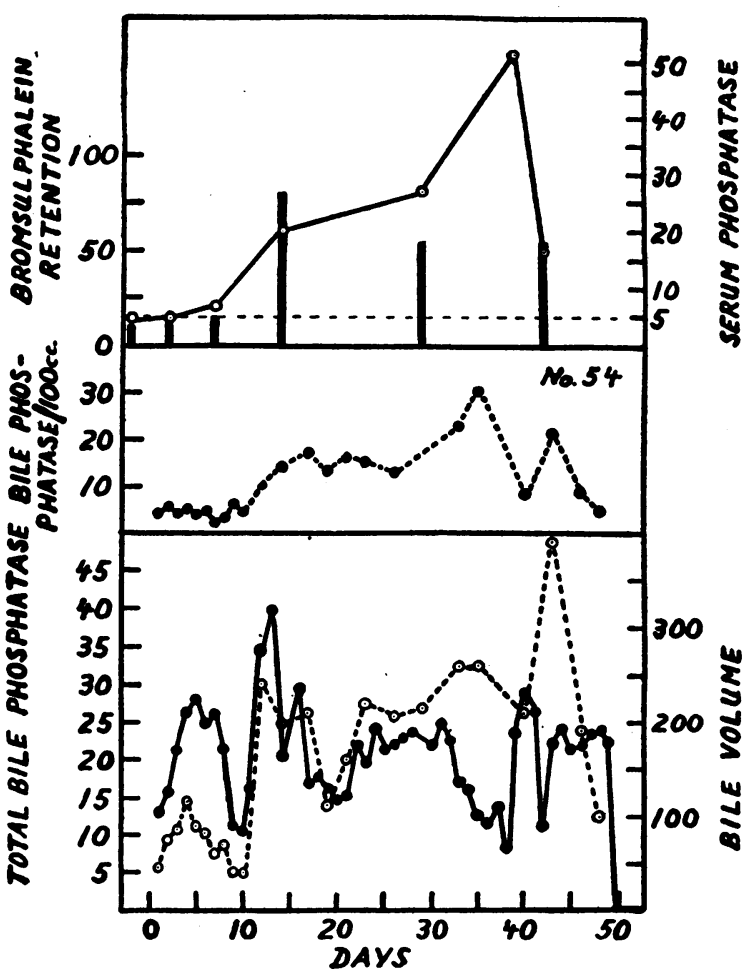

FIG. 4

Figs. 3, 4, and 5. Association of a Rise in Serum Phosphatase with an Increased Excretion of Bille Phosphatase

The rise in serum phosphatase is associated with an increased retention of bromsulphalein. The total output of bile phosphatase per 24 hours is also increased. Solid bars, bromsulphalein; $\odot-\odot$, serum phosphatase; - - - - bile phosphatase per $100 \mathrm{ml}$. of bile; $\odot-. . \odot$, total bile phosphatase per 24 hours; $\bullet \bullet$, bile volume per 24 hours. 


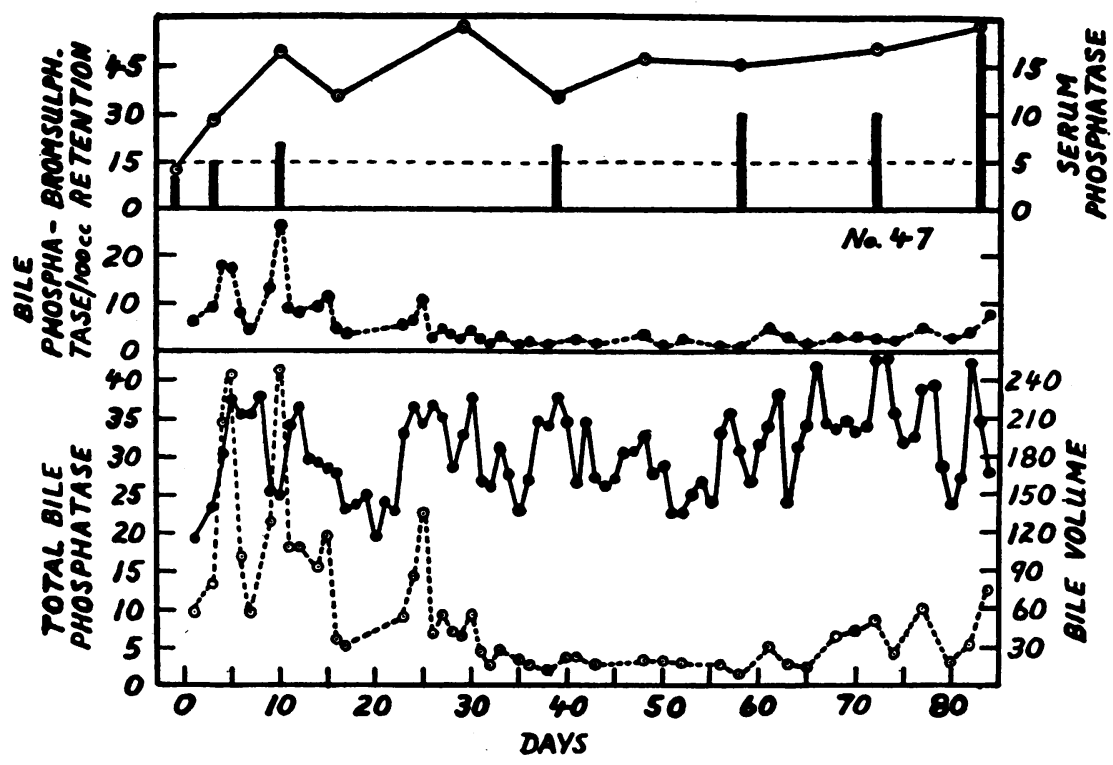

FIg. 6

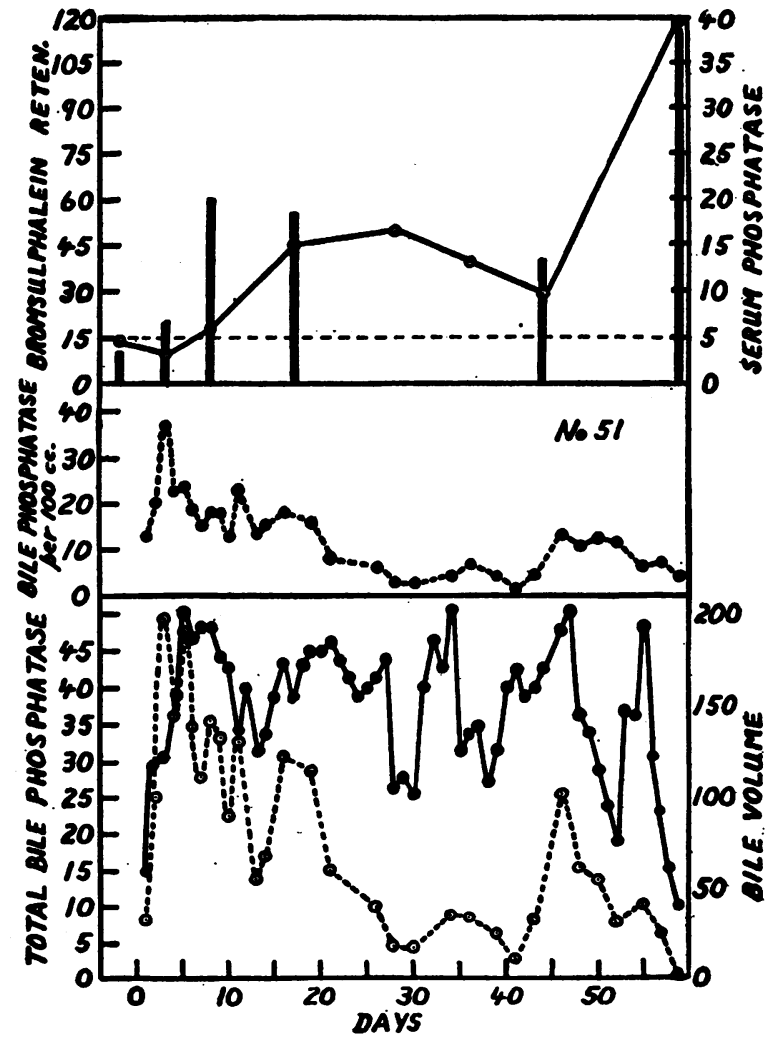

Fig. 7

Figs. 6 and 7. Association of a Rise in Serum Phosphatase with a Decreased Excretion of Bile Phosphatase

The rise in serum phosphatase is associated with an increased retention of bromsulphalein. The total output of bile phosphatase per 24 hours is decreased. Solid bars, bromsulphalein; $\odot-\odot$, serum phosphatase; $\bullet-. .-\bullet$, bile phosphatase per $100 \mathrm{ml}$. of bile; $\odot-. . \odot$, total bile phosphatase per 24 hours; -0 , bile volume per 24 hours. associated with an increased excretion of bile phosphatase, the serum phosphatase probably rising above normal because the animal cannot excrete the phosphatase fast enough. The increased phosphatase presumably comes from the damaged liver, the bromsulphalein test also being abnormal.

\section{RELATION OF FALL IN BILE PHOSPHATASE TO} SERUM PHOSPHATASE, 6 DOGS

In contrast to the previous 3 dogs, the following animals did not have any increase in bile phosphatase excretion associated with the rise in serum phosphatase. They showed instead a marked decrease in phosphatase excretion. This is clearly shown by dog No. 47 (Figure 6), where the phosphatase per $100 \mathrm{ml}$. of bile has fallen, in some instances to less than 1.0 unit per $100 \mathrm{ml}$. The total output of bile phosphatase per 24 hours has likewise fallen to very low levels. With this small excretion of bile phosphatase, the serum phosphatase was maintained at between 10 and 23 units. A slight but continued increase in bromsulphalein retention is also evident, and the bile volume was also nicely maintained at normal levels during the 84 days of observation. Dog No. 51 (Figure 7) shows a similar lowering of bile phosphatase associated with a rise in serum phosphatase and bromsulphalein retention. The high values for the last liver function tests in this dog are due to developing obstruction, as evidenced by the fall in the otherwise normal bile volume. Dogs 53, 66, 81, and 82 (Figures 1 and 2) showed changes in bile phos- 
phatase similar to dogs 47 and 51 ; to conserve space, the values are not shown. In these 6 dogs therefore, the output of bile phosphatase was markedly diminished below normal. The increase in serum phosphatase in these dogs is not due to increased amounts of phosphatase, but rather to failure of the liver to excrete sufficient phosphatase into the bile. It seems probable that serum phosphatase can be raised above normal by the two means so far described.

COMBINATION OF RISE AND FALL IN BILE PHOSPHATASE IN RELATION TO SERUM PHOSPHATASE, 3 DOGS

In dog No. 52 (Figure 8), there was a marked rise in bile phosphatase excretion during the first 20 days post-operatively. Associated with this was a rise in serum phosphatase to 27 units per $100 \mathrm{ml}$. of serum. The excretion of bile phosphatase then fell to a low level and was accompanied by a lowering of the serum phosphatase value. The total excretion of bile phosphatase per 24 hours showed a similar marked change. This dog shows changes in serum and bile phosphatase that we have noted separately in the previous two groups of dogs. First, there was marked increase in bile phosphatase with a rise in serum phosphatase, similar to the dogs in Figures 3, 4, and 5 . Second, this increased formation of phosphatase was not maintained, as evidenced by the decreased biliary phosphatase excretion, and the graph is now similar to the dogs in Figures 6 and 7. If this were merely a failure of the liver to excrete the phosphatase into the bile, the serum level should continue to rise. However, as the decreased excretion of biliary phosphatase was associated with a decline in the serum level,

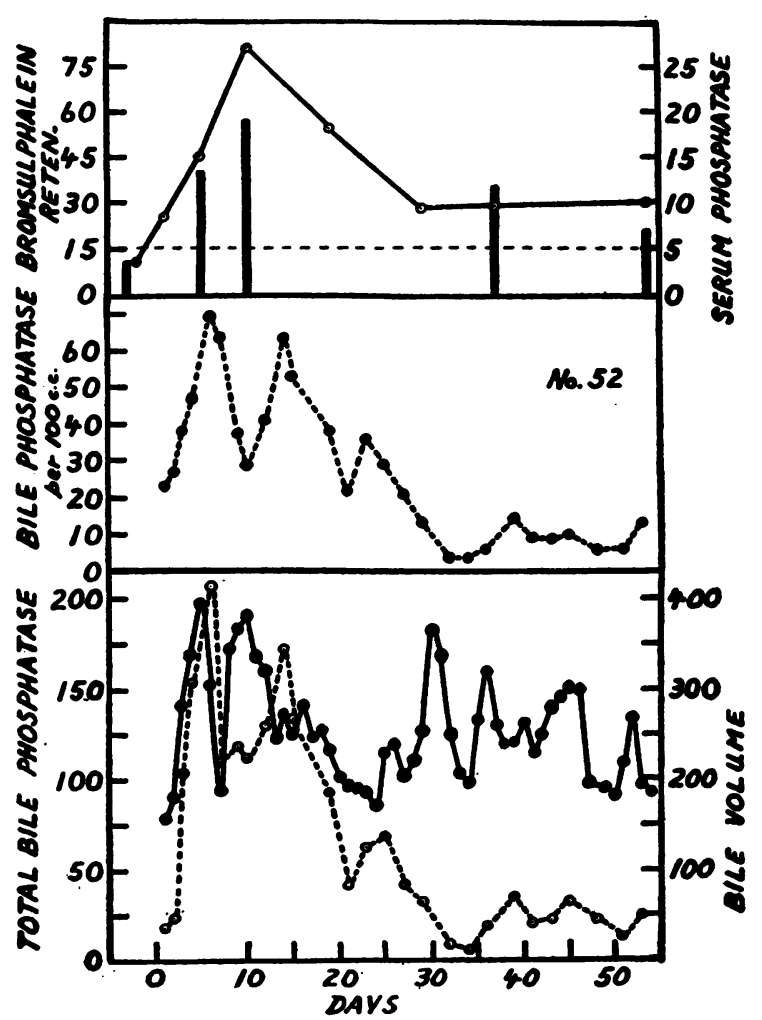

FIG. 8

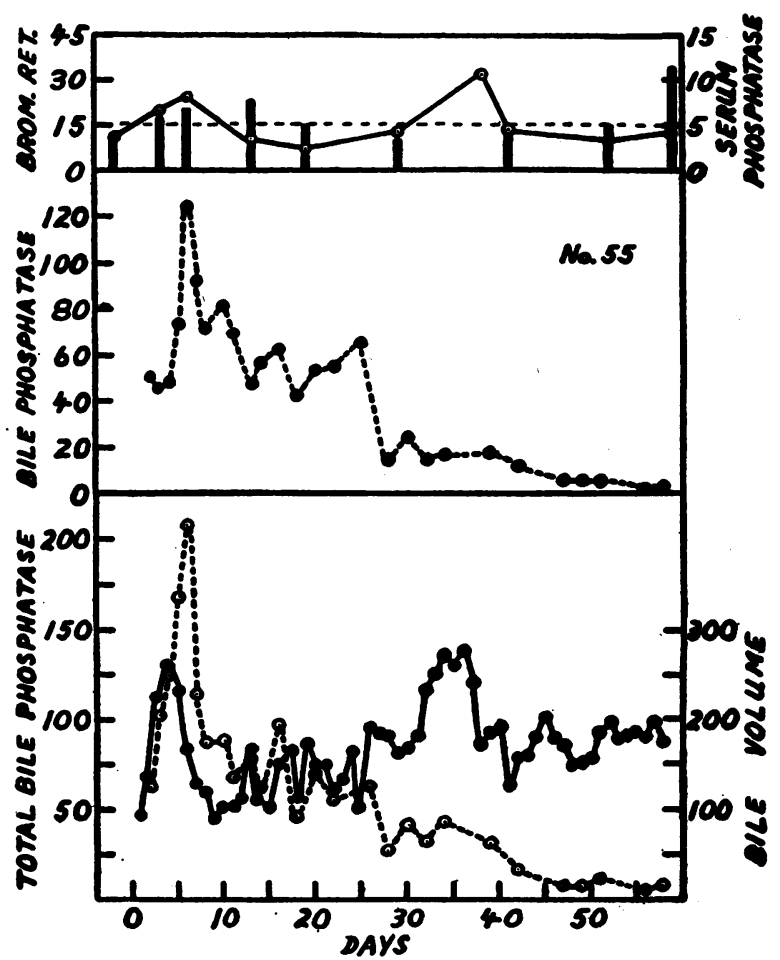

FIG. 9

Figs. 8 and 9. The Graphs Show an Initial Rise of Bile Phosphatase, Followed by a Decrease in Excretion. A Similar Change in the Total Output of Bile Phosphatase per 24 hours is Also Seen

Solid bars, bromsulphalein; $\odot-\odot$, serum phosphatase;..$--\bullet$, bile phosphatase per $100 \mathrm{ml}$. of bile; $\odot-.-\odot$, total bile phosphatase per 24 hours; -0 , bile volume per 24 hours. 


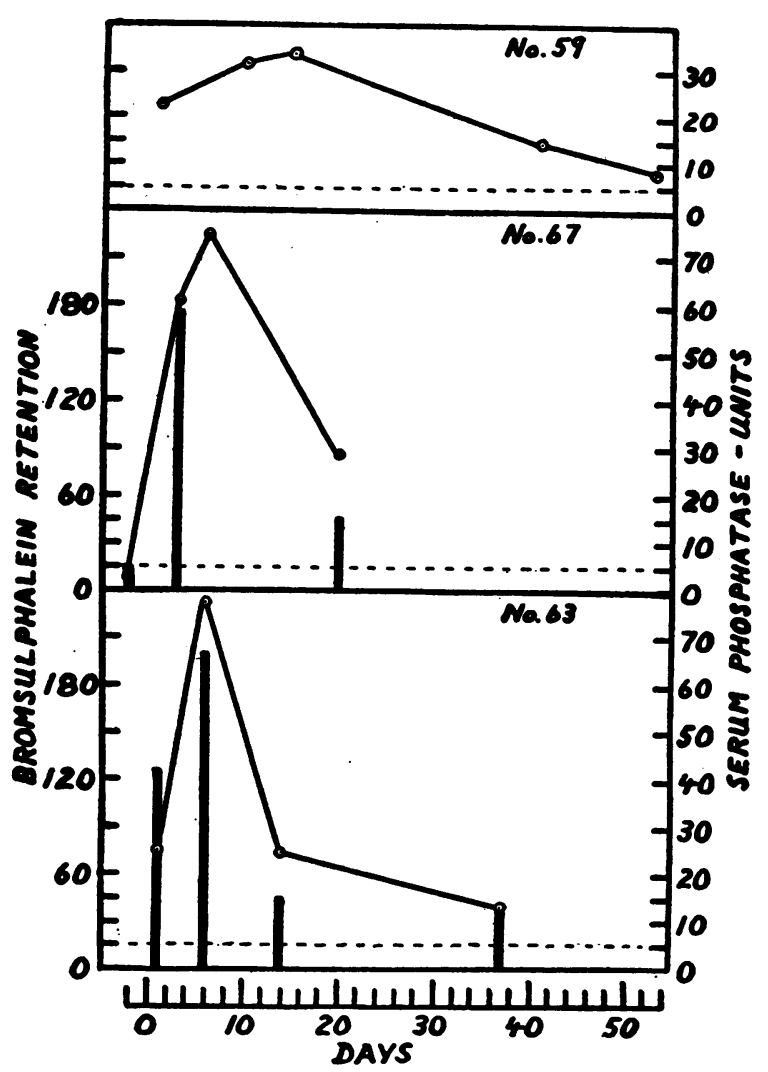

FIG. 10

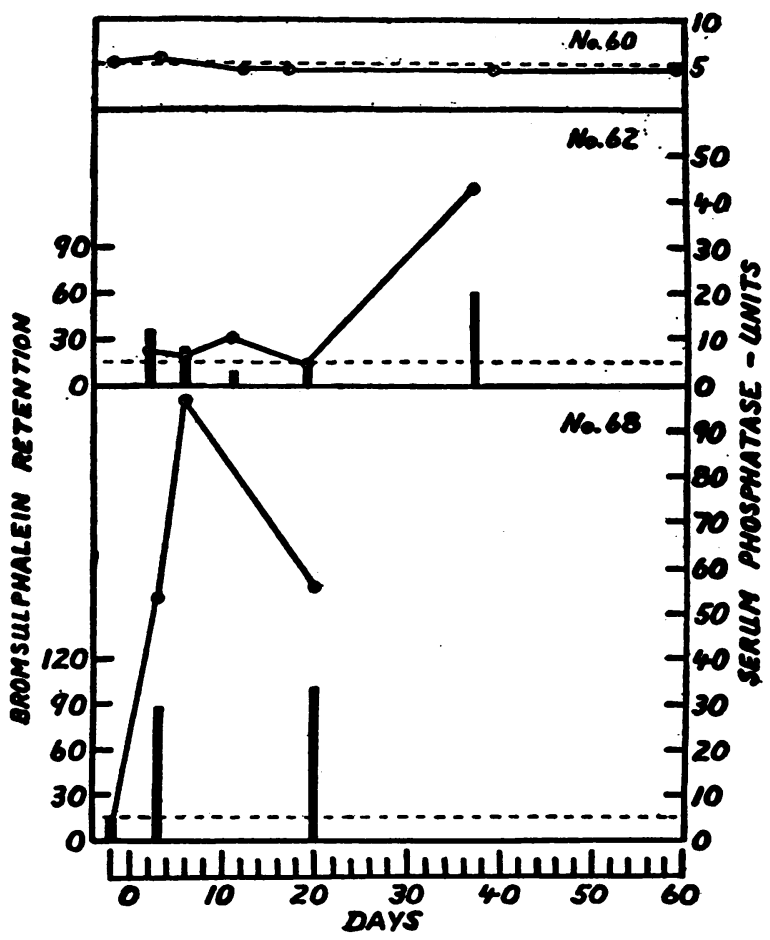

FIG. 11

Figs. 10 and 11. Bromsulphalein Retention and Serum Phosphatase of Internal Biliary Fistula Dogs Solid bars, bromsulphalein; circles, phosphatase units.

there must have been an actual decreased "formation" or "liberation" of the phosphatase. Dog No. 69 (Figure 1) showed a similar, but not as marked a change in bile phosphatase. Dog No. 55 (Figure 9) showed a similar initial high excretion of bile phosphatase which again fell to very low levels. In this dog, the serum phosphatase values returned to normal in all except one reading. Apparently, the "production" of phosphatase was decreased so much, that even with the low excretion, all of the serum phosphatase determinations, except one, became normal. As noted previously, this dog showed the least change in liver function following operation.

\section{INTERNAL BILE FISTULA DOGS}

Six of these dogs were studied post-operatively. Five of the animals showed evidence of considerable hepatic impairment, as judged by the serum phosphatase and bromsulphalein tests, and the dogs were visibly jaundiced (Figures 10 and 11). The sixth dog (No. 60) did not show any significant change in serum phosphatase during the experiment.

\section{DISCUSSION}

The above studies have shown that 14 cholecystectomized-biliary fistula dogs had some degree of abnormal hepatic function following operation. Either one or both of the liver function tests studied remained abnormal in 13 of the dogs throughout the experimental period. In most of the dogs, the bromsulphalein test and serum phosphatase test gave simultaneous evidence of hepatic damage. In 3 animals, the serum phosphatase test gave more indication of hepatic impairment than did the bromsulphalein test, the reverse being true in $1 \mathrm{dog}$. That the liver damage was not merely the result of 
operational trauma can be seen in the graphs. The liver function tests of some of the dogs were normal immediately following operation, becoming abnormal 1 to 12 days post-operatively. Also, many of the dogs showed a progressive increase in liver damage, as the length of the post-operative period increased. Most of the dogs reported in this paper received 1.5 grams of bilron orally twice a day, a few having their own bile returned, and the bile volume was maintained at a normal level throughout the experiments.

No hepatitis or cholangitis occurred as judged from the odor, appearance, bile pigment, cholesterol, and cholic acid content of the bile. Liver sections were not made when the other tests were performed because we desired to follow the dogs until obstruction occurred, which appeared several weeks to months after the changes in phosphatase and bromsulphalein were observed. Thus, changes in hepatic function may be present before changes in the bile chemistry are noted.

To further control the experiments, the bromsulphalein retention and serum phosphatase of 6 internal-biliary fistula dogs were studied. Here, bile was not drained to the outside, but to the renal pelvis for excretion in the urine. Under such conditions, the dye retention and serum phosphatase - showed a sharper postoperative rise than was observed in the previous series of dogs. Some intrahepatic or extrahepatic obstruction must have been present as most of the dogs were jaundiced. As the postoperative period lengthened, the jaundice gradually disappeared. A more severe type of reaction was produced by this operation than in the cholecystectomized-biliary fistula dogs.

The reasons for the hepatic involvement in cholecystectomized-biliary fistula dogs can probably be explained on the known physiology of the biliary tract, as follows: Following cholecystectomy alone (without producing a biliary fistula), the biliary ducts are known to dilate. In the past, this dilatation has been attributed to the loss of regulating function of the gallbladder $(8,9)$. More recent experiments have indicated that following cholecystectomy the sphincter of the ductus choledochous may lose its tone (10 to 12), and allow a constant escape of bile into the intestine; this incompetence of the sphincter of Oddi may result in dilatation of the biliary ducts by transmission of pressure from the duodenum (12). Dilatation of the biliary ducts has also been reported under conditions where any action of the spincter of Oddi is eliminated, such as direct implantation of the common bile duct into the intestine (13) or following cholecystoduodenostomy (14). Thus, the above procedures, by producing a decrease in resistance at the sphincter of Oddi, have produced hepatic changes. In cholecystectomized dogs this effect on the liver can be demonstrated by means of the bromsulphalein and serum phosphatase tests (15). Some similar change would seem to be involved in the present studies on bile fistula dogs, where, in making the fistula, the normal pressure-regulating mechanism of the sphincter of Oddi is circumvented. The hepatic damage noted in these dogs is greater than that observed in cholecystectomized dogs (15).

A mild impairment of liver function in 1 of 4 cholecystectomized-bile fistula dogs following operation has been reported (16). This conclusion was based on a delayed excretion of bromsulphalein in bile, no retention in the blood stream being observed at 30 minutes $(2 \mathrm{mgm}$. per kgm. dose).

The effect of a biliary fistula on liver function is a possible factor that should be taken into consideration in studying the metabolism and excretion of various drugs, bile acids, and bile pigments. The difference in the degree of hepatic damage among the operated animals may produce considerable difference in the results. Further, the possible effects of continued T-tube drainage on hepatic function should also be born in mind.

In the detection of experimental hepatic insufficiency, serum phosphatase determinations are practically as sensitive as the bromsulphalein retention. However, the increase of serum phosphatase above normal varies quite considerably (7). From the above studies on bile fistula dogs, it has been shown that the degree to which the serum phosphatase is above normal is related to the amount of phosphatase excreted in the bile. An increase in' serum phosphatase can be obtained: (1) if the liver fails to excrete phospha- 
tase in the bile; and (2) if more phosphatase is "produced" than can be excreted in the bile. Actually, both changes were apparently found to occur in some of the bile fistula dogs. If we assume the liberation of bone phosphatase into the serum to be constant, then the variations in the output of bile phosphatase and serum phosphatase are probably due to a liberation of phosphatase from the damaged liver. When the liver function was abnormal, a serum phosphatase value only slightly above normal was associated with $a^{\prime}$ decreased excretion of bile phosphatase. With high abnormal serum phosphatase values, an increased excretion of bile phosphatase was observed.

\section{SUMMARY}

1. Fourteen cholecystectomized-biliary fistula dogs developed an abnormal liver function, as judged by the bromsulphalein and serum phosphatase tests, in 1 to 12 days following operation. This change was not merely a post-operative reaction, as the changes developed slowly in most of the dogs, and were maintained throughout the experiment in 11 of the dogs. Two dogs showed a temporary return to normal during the experiment. Bile volume output was normal in all of the dogs.

2. Studies on the excretion of phosphatase in the bile indicate that serum phosphatase may rise (1) due to diminished excretion of phosphatase by the liver, or (2) due to an "increased production" of phosphatase which is not excreted rapidly enough to maintain normal blood values. A combination of both mechanisms was observed in some of the animals.

3. Five of 6 internal-biliary fistula dogs also showed an increased retention of bromsulphalein and a rise in serum phosphatase.

\section{BIBLIOGRAPHY}

1. Drill, V. A., Annegers, J. H., Snapp, E. F., and Ivy, A. C., Liver function and bile phosphatase in bile fistula dogs. Federation Proc., 1943, $2,9$.
2. Rous, P., and McMaster, P. D., A method for the permanent sterile drainage of intraabdominal ducts, as applied to the common bile duct. J. Exper. Med., 1923, 37, 11.

3. Kocour, E. J., and Ivy, A. C., The effect of certain foods on bile volume output recorded in the dog by a quantitative method. Am. J. Physiol., 1938, $122,325$.

4. Schmidt, C. R., Beazell, J. M., Berman, A. L., Ivy, A. C., and Atkinson, A. J., Studies on the secretion of bile. Am. J. Physiol., 1939, 126, 120.

5. Bodansky, A., Notes on the determination of serum inorganic phosphate and serum phosphatase activity. J. Biol. Chem., 1937, 120, 167.

6. Drill, V. A., and Hays, H. W., Hyperthyroidism and liver function in relation to $\mathrm{B}$ vitamins. Proc. Soc. Exper. Biol. and. Med., 1940, 43, 450.

7. Drill, V. A., and Ivy, A. C., Comparative value of bromsulphalein, serum phosphatase, prothrombin time, and intravenous galactose tolerance tests in detecting hepatic damage produced by carbon tetrachloride. J. Clin. Invest., 1944, 23, 209.

8. Ivy, A. C., Physiology of the gallbladder. Physiol. Rev., 1934, 14, 1.

9. Mann, F. C., The functions of the gallbladder. Physiol. Rev., 1924, 4, 251.

10. Puestow, C. B., The discharge of bile into the duodenum. Arch. Surg., 1931, 23, 1013.

11. Cox, F. W., Changes in the bile ducts and parietal sacculi following absence of the gall bladder. Surg., Gynec. and Obst., 1932, 55, 168.

12. Bergh, G. S., Sandblom, P., and Ivy, A. C., Effects of removal of the functioning gallbladder. Surg., Gynec. and Obst., 1936, 62, 811.

13. Giordano, A. S., and Mann, F. C., The sphincter of the choledochus. Arch. Path., and Lab. Med., 1927, 4, 943.

14. Sandblom, P., Bergh, G. S., and Ivy, A. C., Cholecystoduodenostomy combined with pyloric exclusion. Ann. Surg., 1936, 104, 702.

15. Drill, V. A., Annegers, J. H., and Ivy, A. C., Effect of cholecystectomy on liver function. Proc. Soc. Exper. Biol. and Med., 1943, 54, 242.

16. Cantarow, A., and Wirts, C. W., The effect of dog's bile, certain bile acids and india ink on bilirubinemia and excretion of bromsulfalein. Am. J. Digest. Dis., 1943, 10, 261. 